University of Michigan Law School

University of Michigan Law School Scholarship Repository

Articles

Faculty Scholarship

1909

\title{
English Law as an Exponent of English History
}

Edson R. Sunderland

University of Michigan Law School

Available at: https://repository.law.umich.edu/articles/1521

Follow this and additional works at: https://repository.law.umich.edu/articles

Part of the Common Law Commons, Comparative and Foreign Law Commons, and the Legal History Commons

\section{Recommended Citation}

Sunderland, Edson R. "English Law as an Exponent of English History." Mich. L. Rev. 7 (1909): 570-9.

This Article is brought to you for free and open access by the Faculty Scholarship at University of Michigan Law School Scholarship Repository. It has been accepted for inclusion in Articles by an authorized administrator of University of Michigan Law School Scholarship Repository. For more information, please contact mlaw.repository@umich.edu. 


\section{ENGLISH LAW AS AN EXPONENT OF ENGLISH HISTORY}

SPECIALIZATION is commonly said to be the characteristic $D$ feature of contemporary educational development. The world wants men who can do some one thing well or who have penetrated far into the hidden recesses of some single field where they are able to discover something previously unknown. We are even told that breadth of knowledge is a mere euphemism for superficiality, and that general culture is an antiquated relic of a simpler and less exacting age.

It is quite certain, however, that specialization, like most educational enthusiasms, has been much misunderstood, and has indeed proved unprofitable if not positively injurious in its cruder forms. Analysis, to whatever lengths it may be carried, is really only a preliminary step in the broader process of synthesis. Each of the laborers on the Tower of Babel was doubtless as proficient in his work after the confusion of tongues as before, but we are told that the work on the Tower stopped. All were engaged in a common task, and each was helpless when he ceased to understand what the rest were doing. The lawyer, the financier, the historian, the scientist, the engineer, the philologist, the farmer, all are laborers toiling together to extend the limits of human knowledge and expand the scope of human achievement. They must understand one another or the work will stop.

If specialization is carried on in this liberal and catholic spirit it will justify itself in a thousand ways. No man can know everything, but he can by patient exertion broaden himself sufficiently to make his specialized efforts count most effectively. He can understand enough of the trend of human endeavor to keep himself headed in the right direction.

The modern lawyer has always been a specialist of the broad type, perhaps for the reason that he could not help it. Law touches life at almost every point. To know the law one must understand men in their myriad relations. None but a great man can be a great lawyer, for in no other field does narrowness so quickly and so completely bring on disaster.

But strangely enough, while the lawyer feels a keen interest in the efforts of all his fellow men and has built up his own specialty upon the ample foundations of universal knowledge, an understanding of law has not commonly been considered a matter at all vital to laymen, except to enable them to keep out of court. The reason 
for such a provincial view must be found in the prevailing ignorance of law outside of the legal profession. If the specialist in law so constantly draws upon the other departments of knowledge, there is no reason why the converse should not be true. And in the following discussion an effort will be made to suggest how largely the historian may profit from the study of law, and in particular how the facts of English history may be given new significance and vitality by an appreciative understanding of the simultaneous development of English law.

In commenting upon the scope of the subject-matter of history, a learned legal and historical writer, Frederic W. Maitland, says: "The history of history seems to show that it is only late in the day that the laws of a nation become in the historian's eyes a matter of first rate importance. * * * No one indeed would deny the abstract proposition that law is, to say the least, a considerable element in national life; but in the past historians have been apt to assume that it is an element which remains constant, or that any variations in it are so insignificant that they may safely be neglected. The history of external events, of wars and alliances, conquests and annexations, the lives of kings and great men, these seem easier to write, and for a while they are really more attractive; a few lightly written paragraphs on 'the manners and customs of the period' may be thrown in, but they must not be very long nor very serious. It is but gradually that the desire comes upon us to know the men of past times more thoroughly, to know their works and their ways. * * * History then becomes 'constitutional;' even for the purpose of studying the great men and the striking events, it must become constitutional, must try to reproduce the political atmosphere in which the heroes lived and their deeds were done. But it cannot stop there; already it has entered the realm of law, and it finds that realm an organized whole, one that cannot be cut up into departments by hard and fast lines. The public law that the historian wants as stage and scenery for his characters is found to imply private law, and private law a sufficient knowledge of which cannot be taken for granted."1

It is not my purpose to unduly emphasize the light which the study of the laws of a people throws upon its character and development. The teaching of history should be broad enough to recognize the importance of all sides of national life. But I believe therre has never been a sufficient appreciation of the real wealth of suggestive and illuminating material which is contained in the his-

1Materials for the History of English Law. By Frederick W. Maitland. (Select Essays in Anglo-American Legal History, Vol. 2, pp. 53, 54 . 
tory of English law. For the English have been pre-eminently a legal race. In the study of Roman History Roman Law has always occupied a prominent place. The Romans made their reputation, so to speak, on their conquests and on their law. They did not borrow their legal system, but they created it. Now the same is true of the English, and in that respect they stand practically alone among modern European nations. The continental nations, with the ,exception of the Scandinavians, merely appropriated the civil law of Rome. England developed a separate, distinct and characteristic legal system which differed radically from the Roman law. It grew up as an embodiment of the social, industrial, religious and political experiences of the English people. It was native, and therefore was a manifestation of the inherent qualities of the race. So that I believe it may be said of England far more than of any other Eluropean nation of today that her laws are the records of her life.

This is recognized to a limited extent in the common text-books on English history, but the laws which are prominently referred to are those which determine the political status of the people rather than those which deal with the private rights of person and property. The latter, however, are even more characteristic and interesting than the former, and by a study of their growth we may see the close and intimate correlation which exists between the progress of English law and the moral, social and industrial development of the people.

We in this country are very familiar with the three-fold governmental system which was adopted by. the authors of the Constitution of the United States. The legislative functions of government are lodged in one body, the judicial in another, and the executive are separate from both. Each State in its own constitution has adopted the same theory of the division of governmental functions. This is the only system with which we are practically acquainted, and we are likely to assume that it is peculiarly well adapted to our ${ }^{\circ}$ free institutions and to our Anglo-Saxon temperament and traditions.

As a matter of fact, it is not a system native to the English race, but was the product of the French political philosophy current at the time of the establishment of this nation.

According to this constitutional theory of government all rules of law are adopted and given force by the legislative branch, and the sole function of the courts is to administer those rules. Now it is a curious feature of the development of English society that the courts have not only been the agencies for administering the laws but have done fully as much as, and probably more than, Parliament itself 
in making them. And this making of laws by the courts has gone on in an unostentatious but exceedingly effective way down to the present time.

The system of judicial legislation here referred to is, $I$ believe, one of the essential and distinguishing characteristics of English law, and it is the one aspect of English legal development which more than any other has tended to produce an intimate and organic interrelation between English law and English life.

It is a fundamental maxim of English law, developed very early, that there is no right without a remedy. Ubi jus, ibi remedium, as the maxim reads. In other words, every right will be protected by the courts. If the legislature has provided a remedy such remedy will be given in a proper case, but if the legislature has failed to do so the courts will give a remedy which seems appropriate. The question, therefore, with which the suitor is concerned is not whether there is a remedy for a wrong, but whether he has any right which has been infringed. If a right is recognized his remedy follows as a matter of course. Right and remedy are therefore correlative terms. Given one, the other follows.

Now the significant thing about this maxim is the order in which the terms appear. Suppose it read, "Where there is a remedy there is a right." The question then would be, "Is there a remedy?". If there is none the suitor has no right. The vast difference between these two positions' becomes clear by a moment's reflection. - Rights are inherent in men; remedies are supplied by the injured party or by his friends or by society. Rights are natural; remedies are artificial. All men are endowed by their Creator with certain inalienable rights; there is no such endowment in remedies. Rights are recognized by the moral sense and appeal to the conscience; remedies are mere conventional processes of which one may be as good as another.

Now if a remedy will be granted whenever there is a right, remedies, become purely incidental matters. One may establish his right by an appeal. to the conscience of the court. If the judge recognizes the fundamental justice of his case he obtains relief. Hence, under this theory, as society develops and the social conscience defines and recognizes new rights growing out of new situations, the remedies must keep pace. The litigant's rights depend not on what the legislature has done, not upon any external thing whatever, but upon the innate reasonableness of his demand. Every judge, as a member of society;,interprets the social will, and the rights which society broadly recognizes he will recognize and protect.

If, on the other hand, the maxim were reversed, the judge would 
be obliged to look, not to the spirit working in the social, fabric, not to the social conscience, not to moral tests, but to the existence and character of those arbitrary, conventional and purely formal processes which society or the state had placed at his disposal.

Inasmuch, therefore, as the English moral sense and spirit of justice early formulated and insisted upon the notion that the right was the main thing, the remedy secondary, a foundation was laid for the systematic development of English law through the action of the judges in passing upon cases as they were presented for trial. The suitor had to show the justice of his claim; if he did that he won his case and his remedy followed as an incident.

Now, it is very obvious that if many courts passed upon many cases, and the success of a party's claim depended upon so vague and ill-defined a criterion as the judge's sense of justice, the law might soon be expected to présent a most checkered appearance. Matters which would appeal to the conscience of one judge would not appeal to another. The rights of litigants might therefore be expected to vary in different local jurisdictions and to change with each change in the personnel of the courts.

But this did not happen. If it had the legislature would doubtless have stepped in and attempted to limit the discretion of the judges by a legislative enumeration of personal rights. Instead the judges developed a system of uniformity by a resort to precedents. And this is the second great characteristic of English law to which I wish to refer.

English law is primarily the product of litigation, not legislation. The judges found and declared and thereby established the rights of parties. If a man considered that he had been wronged by another he went into court for a remedy. On what did he base his hope of receiving what he sought? On two things: (I) the inherent justice of his cause; (2) the fact that some other man had once sued his neighbor in a similar case and had recovered. These were the two reasons which led a plaintiff to go to law. They were equally the two factors which determined the action of the judge in disposing of the case. But the judges, like all conscientious men who are habitually required to pass upon the rights of others, were conservative. The plaintiff might seem to have a just case, but on the other hand the defendant might have acted in good faith and intended no wrong. Should the defendant be made to suffer or were there extenuating circumstances which should operate to' excuse? Most contests have two sides. A just decision is usually a.difficult thing to reach. Judges are human and fallible. To decide a hard case entirely on principle, without further assistance, is a hazardous under- 
taking. What more natural than for the judge to investigate the holdings of other judges in similar cases to see what help could be derived from their observations and analyses? So arose the system of reference to precedents. If there were no prior case in point the plaintiff might nevertheless succeed if his right was entirely clear, but in a doubtful controversy his position was immensely strengthened by showing that the right he claimed had already been judicially recognized and enforced.

- It is a natural human trait to endeavor to shift responsibility upon others rather than to carry it one's self, particularly when one's acts will seriously affect the rights of third persons and no element of self-interest complicates the situation. At least the judicial trend has always been in that direction, and when the system of reference to precedents became well established the judges showed an increasing reluctance to recognize new rights not based on former adjudications. More and more rarely did a suitor succeed who went into court with nothing but the inherent justice of his case to present to the judge; and more and more rairely did he try it. A precedent must be found, and the ingenuity of lawyers and judges devoted itself to analyzing former cases to see whether or not they could be deemed to sanction the particular claim in litigation. If no case could be found which disclosed the same state of facts, it was argued that at least the principle involved in some reported case was identical with that sought to be invoked, and old cases in this way were enlarged in their operation and effect as authorities, and were used to support claims of which the judges who decided them never dreamed.

But the conservatism of the courts constituted a barrier in the way of a really liberal expansion of the law in this way. Standing as they did with their eyes fixed on the past, solving contemporary problems with the crude instruments of an outgrown age, it was not strange that the judges little by little became narrow and technical, and failed to respond to the new demands of a developing society. Pomeroy says that "the history of civilized jurisprudence can show nothing of the same kind comparable with the blind conservatism with which the common law judges were accustomed to regard the rules and doctrines which had once been formulated by a precedent, and the stubborn resistance which they interposed to any departure. from or change in either the spirit or the form of the law which had been thus established."'2

And Spence, contrasting the plastic developing period of the common law with the later rigid and fixed form in which it became cast, declares that "As long as the common law was in the course of for-

2Pomeroy Eq. Jur., 15. 
mation, and therefore continued to be a lex non scripta, it was capable, as indeed it ever continued to be to some extent, of not only being extended to cases not expressly provided for, but which were within the spirit of the existing law, but also of having the principles of equity applied to it by the judges in their decisions, as circumstances arose which called for the application of such principles. But in the course of time a series of precedents was established by the decisions or responsa, as Bracton calls them, of the judges, which were considered of almost equally binding authority on succeeding judges as were the acts of the legislature, and it became difficult to make new precedents without interfering with those which had already been established. Hence (though new precedents have ever continued to be made) the common law soon became to a great extent a lex scripta positive and inflexible; so that the rule of justice could not accommodate itself to every case according to the exigency of right and justice."3

In this state of affairs it would have seemed proper, perhaps, for Parliament to take a hand and by legislative enactment strike off the shackles which were killing the free spirit of the law. An effort of this kind was in fact made. But that was not the English way. The law should develop from within rather than by external forcing, and a remedy grew up which constitutes the third great characteristic of English law, namely, the existence of chancery or equity jurisdiction as separate and distinct from the common law jurisdiction.

There is no logical reason why a single court should not administer the whole law, recognize all rights and grant all remedies. There is absolutely no inherent necessity for dividing up personal rights into two arbitrary classes, one called legal and the other called equitable, and placing one class under the jurisdiction of one set of courts and the other under the jurisdiction of another set of courts. No other nation than the English ever devised such a scheme. But the English did so and we have followed them, and today all the United States courts and the courts of half the States are divided into two classes, courts of law and courts of equity, sitting at different times, recognizing different rights, enforcing different rules of procedure and granting different remedies.

As to the origin of chancery jurisdiction, it is shrouded in the mists of uncertainty, but it is clear that from early times a sort of prerogative jurisdiction was retained by the king, covering cases not coming within the ordinary scope of the common law courts. When the king had no time to devote to the judicial matters coming before him they were turned over to a Special Council composed of the Chancellor,

3 I Spenice Eq. Jur. 321, 322. 
the Treasurer, the Chief Justiciary and other appointees of the king. And in turn the other members of the Council, being themselves busy with affairs of state, began delegating to the Chancellor the authority to deal with these prerogative cases. This practice grew up gradually, ànd was at length confirmed by a general writ in the reign of Edward III, whereby it was ordered that all such matters as were of Grace should be referred to and dispatched by the Chancellor. The principles upon which the Chancellor based his decisions were Honesty, Equity and Conscience. Could any theory of justice be more generous and comprehensive!

One restrictive feature of the common law practice never obtained recognition from the Chancellor, namely the necessity of a royal writ for the institution of suit. The common law courts could not acquire jurisdiction of a case unless a writ first issued. The writs were rigid and formal documents strictly limited in their scope to certain specific kinds of cases, and when a new case arose, for which there was no suitable writ, the plaintiff had no way of getting into court at all except through the liberality of the judges in stretching some old writ to cover the analogous new case. For a while this was done, but when the common law judges became technical and narrow in their construction of precedents they also lost their broad and tolerant practice respecting the use of writs, and suitors found themselves bound with a double chain, the identical writ and the identical precedent.

The Chancellor was free from these restrictions. What, then, more natural thán for the suitor who found no relief in the common law courts to take his case to the Chancellor! And so arose the chancery jurisdiction supplementing that of the common law, and as it grew in volume chancery judges were appointed to help the Chancellor dispatch the business. If a suitor had án adequate remedy at law he was not permitted to go into chancery, and such is still the rule, but if he had no standing before the common law judges he was welcomed in the Chancellor's court of conscience.

Naturally the chancery became very popular and the common law courts were more and more neglected. And equally natural was the feeling which began to develop among the common law judges that they were killing their own courts by driving suitors into chancery. Accordingly they began to compete for business and little by little dropped the technical and antiquated notions which had made common law administration something of a mockery of justice. But the respect for precedent was still sufficient to restrain the common law courts from a radical departure from their immemorial practices and from taking up the novel and foreign remedies which the chancery 
had largely adopted from the law of Rome. So the two systems lived and grew together, each supreme in its own field, each doing its own work in securing to the people of England full and adequate protection to person and property. And today, in many States, if one wishes to know whether his rights in a given case are legal or equitable and whether he must go into a court of law or may appeal to the conscience of the Chancellor, he must consult the decisions of the old law and chancery judges who sat in England during the last three hundred years.

It would be interesting, after this general consideration of conspicuous characteristics, to follow out some of the details of the common law and equity development, to trace the evolution of legal standards of personal conduct, to see how the specific principles of the law have exacted from men the most scrupulous regard for honesty and integrity, and to see how legal standards have tended to lead rather than follow current practices. It would be interesting to follow the development of the separate branches of the law, to see how the liability for doing a wrongful act was extended to cover the careless doing of a rightful act, and how this in turn led to the rule imposing liability for the failure to do an act which should have been done, thus producing the modern law of negligence.

It would be full of illuminating suggestions to trace the law of fraud from its grosser earlier forms to the modern refined doctrines of constructive fraud, an evolutionary process that well illustrates the severity of the moral principles which recognized law as a branch of ethics. One would gain a new respect for the high character of the English race by following the steadily rising ideals of the trust relation which the courts have brought to so lofty a plane that one is not permitted to occupy a position of trust under conditions which in their nature even tend to promote dishonesty, though he show that his conduct is wholly exemplary and without a taint of fraud. The industrial development of England is nowhere more accurately depicted than in the growth of the law of partnership, negotiable instruments and bailments. And in more modern times the rise of that great instrument for the accomplishment of vast financial undertakings, the corporation, throws a flood of light upon the industrial revolution in the toils of which we are still struggling. But it is sought here merely to show in a general way that the history of English law is a peculiarly intimate part of the history of the English people, and that a knowledge of one is essential to a real understanding of the other. 
Law is not something apart from life. It is not an esoteric mystery whose secrets are revealed only to the initiated. It is not even particularly technical. Everyone who will may read it and understand it, and among all who do so none will find it more illuminating than the student of English history.

EDSON R. SUnDERLAND.

UNIVERSITY OF MichigAN. 